\title{
ASM meeting: Looking for bugs in all the odd places
}

\section{Fungi and bacteria frozen in time}

Ever since Alpine hikers accidentally discovered the remains of the 5,300-yearold Iceman in 1991, researchers have focused either on his anatomical features or on the artefacts found with the body. But the fascination with how the Iceman lived is matched by scientific interest in what lived on him.

"We are trying to get an idea of what kind of microorganisms were colonizing that individual at or near the time of his death," says Raúl Cano, head of the Ancient DNA laboratory at California Polytechnic State University in San Luis Obispo, California. Cano and his collaborators have been analysing endoscopic lung samples from the Iceman for the presence of fungal and bacterial DNA since 1994, when they first received samples.

By using the polymerase chain reaction (PCR) technique, the researchers demonstrated the presence of both Aspergillus and Bacillus DNA sequences in the Iceman's lungs. The lung flora appear "similar, but not identical" to contemporary strains, according to Cano.

The implications of this discovery were misunderstood at first. "I mentioned during a press conference that Aspergillus has been associated with some human death," says Cano, "but someone then

\section{IMAGE UNAVAILABLE FOR COPYRIGHT REASONS}

Using PCR, researchers have revealed the presence of bacteria and fungi lurking in the Iceman's lungs.

drew the conclusion that Aspergillus killed the Iceman." He emphasizes that the cause of the Iceman's death is still unknown. Most researchers believe he merely fell asleep and froze to death.

Cano and his collaborators hope to replicate their previous results, as well as extend the research to search for other microorganisms. Their successful and reproducible isolation of Bacillus DNA from 25- to 40-million-year-old, amber-encased bees gives them confidence that they will re-
Every one of the more than 13,000 participants in the 95th General Meeting of the American Society for Microbiology (ASM), held 21-25 May in Washington, DC, takes a different approach to the study of microscopic flora and fauna. In fact, the only theme that carried throughout the large meeting was that microscopic beasties are everywhere, from the the deepest oceanic thermal vent to the fibres of the Shroud of Turin (see Nature Medicine 1, $495 ; 1995)$. As many researchers know, it is too easy to miss interesting presentations at such mega-meetings. Therefore, for the few who were unable to attend the meeting in person, we offer a microbiological sampler of the critters lurking in every crevice.

cover even more information from the Iceman. However, their research is hampered by the politics surrounding 'ownership' of the Iceman (an ongoing and unresolved battle between Italy and Austria).

\section{Consubstantial creatures}

Perhaps in the category of 'some stones may be better left unturned,' a presentation by Anne LaGrange Loving, a microbiologist at Felician College in Lodi, New Jersey, focused on the bacteria transferred during Holy Communion. Concerns about the sanitariness of drinking from a common communion cup has led some churches to practice 'intinction', that is, dipping the wafer in the wine and then consuming them together, a controversial practice for theologians and microbiologists alike. (Theologians question the symbolic value, but microbiologists question the sanitariness, as intinction still involves fingertips, lips and jointly shared utensils.)

Using "a sterling silver communion chalice, altar wine, communion wafers, and a variety of standard microbiological supplies," Loving conducted two "simulated Holy Eucharist services" and sampled the fingertips of the participants, as well as the wafers and the wine, for the presence of bacteria. Although the majority of bacteria isolated were "normal skin bacteria," 30 per cent of the cultures contained other microorganisms, including faecal bacteria (Escherichia coli) and the pathogen Staphylococcus aureus.

Although intinction may be more sani- tary than drinking from a common cup, LaGrange Loving's studies suggest that there are more than theological objections to consider. The results of her study will be published later this year in the Journal of Environmental Health.

\section{Getting a fix on oral bacteria}

Recent high-tech commercials tout the germ-fighting ability of a popular mouth wash, graphically reminding the viewer that the human mouth is a living Petri dish of nasty microorganisms. Two of these, Actinomyces viscosus and Fusobacterium nucleatum, are implicated in the development of gingivitis and other tooth and gum disease.

As dental hygienists repeatedly preach to captive believers, regular flossing can significantly reduce the incidence of such diseases. A presentation at the ASM meeting added even more muscle to the antimicrobial effects of flossing: a new dental floss that contains an antimicrobial agent that can kill virtually 100 per cent of the bacteria against which it was tested.

"As far as I know, we are the only ones pursuing this [research]," says James J. Barbato of the Massachusetts College of Pharmacy and Allied Health Sciences, who presented his studies at the meeting. They showed that the dental floss killed bacteria on contact in vitro.

\section{IMAGE UNAVAILABLE FOR COPYRIGHT REASONS}

False-colour scanning electron micrograph of rod-shaped bacteria (red) on the surface of a human tooth (yellow). Magnification: $\times 780$.

The antimicrobial agent in the experimental dental floss, chlorhexidine, is also used in hand-washing solutions and prescription mouthwashes. It doesn't appear to have toxic side-effects, nor has it been shown to select for resistant bacteria.

The next step is to show that the dental floss can kill bacteria by using it in animals, possibly dogs. While flossing canines carries some danger, the researchers are optimistic that the floss will prove effective in vivo.

FinTan R. Steele 